\title{
Antifilarial activity of Butea monosperma L. leaves extracts against Setaria cervi
}

Madhuri Deshmukh, Keertisheel N. Sahare, Rakesh Kumar Patidar, Bharti Mahajan and Vinod Singh*

*Correspondence: vsingh3@rediffmail.com

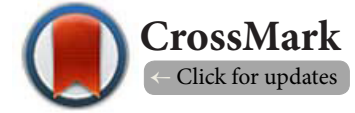

Department of Microbiology, Barkatullah University, Bhopal, Madhya Pradesh, India.

\begin{abstract}
Background: Usage of herbal drugs in traditional medicine is quite well known but largely empirical. Hence the present study was designed to screen the in vitro antifilarial effect of Butea monosperma L. plant leaves against Setaria cervi.

Methods: Antifilarial activity of Methanol/Hexane-ethanol extracts of Butea monosperma L. (leaves) and Ciprofloxacin was explored against adult of Setaria cervi after incubation for $24 \mathrm{hrs}$ with concentration range of 0.25 to $20 \mathrm{mg} / \mathrm{ml}$ for possible antifilarial effect by comparing with suitable control, in terms of motility inhibition assay and MTT reduction assay.

Results: Butea monosperma L. plant leaves showed significant antifillarial activity against adult as compared to controls whereas activity demonstrated by Ciprofloxacin was comparatively less significant. Inhibitory concentrations (IC50) for the plant extracts with significant antifilarial activity against Setaria cervi adult in vitro system have been derived to be $1.25,3.6 \mathrm{and} 7.5 \mathrm{mg} / \mathrm{ml}$ Methanol, Hexane-ethanol extracts and Ciprofloxacin respectively.

Conclusion: The present research investigation proved to be an additional frame in recording the plant extract's antifilarial activity. Methanol and Hexane-ethanol extracts of Butea monosperma L. plant leaves which shown significant antifilarial activity. The present research data highlights the importance of further depth research in this area.
\end{abstract}

Keywords: Filariasis, in vitro, Drug discovery, Setaria cervi, Butea monosperma $\mathrm{L}$

\section{Introduction}

Lymphatic filariasis is a vector-borne parasitic disease, caused by nematodes (roundworms) parasitic species Wuchereria bancrofti, Brugia malayi, and Brugia timori. Lymphatic filariasis causes of disfigurement and disability in endemic areas, leading to significant economic and psychosocial impact. In India, around $45 \%$ of its 1-billion plus population lives in known endemic areas and 48 million are infected [1], accounting for $40 \%$ of the worldwide filariasis burden [2]. Socioeconomic studies showed that the annual loss caused by this disease is near to a billion U.S. dollars [3]. Diethylcarbamazine (DEC) is the drug of choice to treat patients suffered from filariasis. DEC kills circulating microfilariae and it is less effective against the adult worms. Adult worms may survive for several years in the infected person producing microfilariae and thereby facilitate transmission of the disease through the vector mosquitoes to more individuals. Hence elimination of the parasite by means of microfilaricide alone is extremely difficult [4]. Precisely because of these reasons, it is quite imperative to find out novel antifilarial drugs against the adult filarial worms. The World Health Organization (WHO) has already outlined the nature of traditional medicine including herbal therapeutics [5]. Plants are rich in resource materials for numerous phytomedicine utilized in traditional therapeutics. Plant based active principles can be derived from any part of the plant like bark, leaves, flowers, roots, fruits, seeds, and the others [6]. With the perspective of these encouraging advancements, in the present study plant Butea monosperma $\mathrm{L}$. leaves was screened in vitro for their possible antifilarial activity against Setaria cervi adult filarial parasite.

\section{Materials and methods \\ Procuring plant material}

Leaves of Butea monosperma L. plant leaves (palash) were collected from campus of Barkatullah University, Bhopal in the month of Jan 2013. The botanical identity was confirmed by a botanist Prof. Zia-Ul-Hasan Department of Botany, Safia Science College, Bhopal and reference No. 407/Bot./Safia/15 allotted.

\section{Extraction}

The leaves of medicinal plant were washed, shade dried and powdered. The powder of Butea monosperma $\mathrm{L}$. plant leaves were extracted with Petrolium ether, Hexane-Ethanol and Methanol respectively $[7,8]$. Different concentrations of extract were prepared by dissolving the extract in Dimethylsulfoxide (DMSO, Merck, Drug use grade) for further study.

\section{Parasite}

Adult Setaria cervi were obtained from the peritoneal cavity of freshly slaughtered cattle. The worms were washed repeatedly with normal saline $(0.85 \%)$ to free them of any extraneous 
material and used for assay.

\section{In vitro motility inhibition assay}

The worms were transferred immediately to DMEM (Dulbecco's modified eagle's medium) (Hi-Media, Mumbai, India) with $0.01 \%$ Strepto-penicillin (Hi-Media, Mumbai, India) and supplemented with $10 \%$ heat-inactivated fetal bovine serum (Hi-Media, Mumbai, India). Dilutions of the methanol/hexane-ethanol extract of Butea monosperma L. plant leaves and antibiotic Ciprofloxacin were made in DMSO (Dimethyl sulphoxide) (Merck India, drug use grade) in such a way that $100 \mu \mathrm{L}$ of which, when distributed to sterile disposable Petri dishes (35- $\mathrm{mm}$ diameter and $5-\mathrm{mL}$ capacity) containing $3 \mathrm{ml}$ medium would give the required test concentration. Screening was done at concentrations ranging from 0.25 to $20 \mathrm{mg} / \mathrm{ml}$. A simultaneous control was kept without the test solution but with $100 \mu \mathrm{l}$ DMSO in $3 \mathrm{~mL}$ of the medium. One male and female worm introduced into each petri-dish. Three replicates each were set up for both test and control. The worms were incubated at $37^{\circ} \mathrm{C}$ in $5 \% \mathrm{CO}_{2}$ incubator for $24 \mathrm{hrs}$. Motility observed after 5-24 hrs respectively. After exposure, the worms were washed twice with fresh medium and transferred to another set of fresh petridish containing fresh medium without the test solution to find out whether any of the immotile worms regained motility in the 2 hrs post treatment period in drug free Medium. If the worms did not revive, the condition was considered as irreversible and the concentration lethal. Each experiment was repeated thrice [9].

\section{MTT Formazan colorimetric assay of crude extract}

Effect of crude plant extracts on adult female Setaria cervi worms was studied by MTT (3-[4, 5dimethylthiazol-2-yl]2,5-diphenyl tetrazolium bromide) (Hi-media, Mumbai, India) - Formazan reduction assay following the method described by Comely et al., [10]. Because of the scarcity of male worms only female worms were used for these tests. The parasites were further incubated for $30 \mathrm{~min}$ individually in $0.5 \mathrm{~mL}$ phosphate buffered saline $(\mathrm{pH} 7.4)$ containing $0.25 \mathrm{mgmL}^{-1}$ MTT. At the end of the incubation, worms were carefully transferred to a microtiter plate containing $400 \mu \mathrm{L}$ of DMSO (Hi-media, Mumbai, India, Spectroscopic grade) and allowed to be at room temperature for $1 \mathrm{hrs}$, with occasional gentle shaking to extract the colour developed. The absorbance of the resulting formazan solution was then determined at 492 $\mathrm{nm}$ in an enzyme-linked immunosorbent assay reader (ELISA plus, Microtitre plate reader) relative to DMSO blank. High values of absorption correlate with high viability of the worms. Adult worms that had previously been heat killed $\left(56^{\circ} \mathrm{C}\right.$ for 30 min) and incubated with MTT served as the negative control. Viability of the worms was estimated as percentage inhibition in formazan formation relative to solvent controls and heat killed worms [11] by following the formula:

$\%$ inhibition reduction (parameter) $=100-[(\mathrm{T}-\mathrm{H}) /(\mathrm{C}-\mathrm{H})] \times 100$

Where $\mathrm{T}, \mathrm{C}$, and $\mathrm{H}$ are absorbance values obtained for the formazan produced in treated, control, and heat killed worms respectively.

\section{Statistical analysis}

The results were expressed as mean \pm s.e.m for the triplicate observations made in each observation. For comparison of means of different parameters between the test plant extracts and respective controls, Student's t test was used. $P$ values of $<0.05$ were considered as significant.

\section{Results \\ Preparation of plant extract}

The solvent removed from the plant extract under reduced pressure and semisolid extract obtained.

\section{In vitro motility inhibition assay}

Crude extract of Methanol, Hexane-ethanol and antibiotic Ciprofloxacin was used for antifilarial screening against adult parasite Setaria cervi. Concentrations for Methanol and Hexane-ethanol extract 0.25 to $5.0,0.50$ to $10.0 \mathrm{mg} /$ $\mathrm{mL}$ and for Ciprofloxacin concentration 1.0 to $20.0 \mathrm{mg} / \mathrm{mL}$ caused complete immobilization of the worms at 5 to $24 \mathrm{hrs}$ exposure respectively at $37^{\circ} \mathrm{C}$, whereas in untreated control, all the worms were active (Table 1). Post exposure incubation in fresh medium (without test solution) for $2 \mathrm{hrs}$ did not revive the worms, confirm their death due to the treatment by drug. The results shown that at high concentrations of drug, the inhibition in motility was faster, while at lower concentrations it was comparatively slow.

\section{MTT-reduction assay}

The adulticidal effect of the plant extracts and Ciprofloxacin was confirmed by comparison of the treated worms to un-

Table 1. Antifilarial activity of Butea monosperma L. leaves extract/Ciprofloxacin against adult filarial parasite in terms of motility inhibition assay.

\begin{tabular}{llllll}
\hline $\begin{array}{l}\text { Methanol extract } \\
\left(\mathbf{m g m L}^{-1}\right)\end{array}$ & $\begin{array}{l}\text { Hexane-ethanol extract } \\
\left(\mathbf{m g m L}^{-1}\right)\end{array}$ & $\begin{array}{l}\text { Ciprofloxacin } \\
\left(\mathbf{m g m L}^{-1}\right)\end{array}$ & $\begin{array}{l}\text { Incubation time } \\
(\text { end point }) \text { in hrs }\end{array}$ & $\begin{array}{l}\text { Worm motility inhibition } \\
(\text { Test })\end{array}$ & $\begin{array}{l}\text { Worm motility } \\
\text { inhibition }(\mathbf{C o n t r o l})\end{array}$ \\
\hline 0.25 & 0.50 & 1.00 & 24.0 & 100 & 0 \\
0.50 & 1.00 & 2.00 & 20.0 & 100 & 0 \\
1.00 & 2.00 & 5.00 & 15.0 & 100 & 0 \\
2.00 & 5.00 & 10.0 & 10.0 & 100 & 0 \\
5.00 & 10.00 & 20.0 & 5.0 & 100 & 0 \\
\hline
\end{tabular}


treated control and heat-killed worms, in terms of MTTformazan colorimetric assay. MTT is light yellow in solution, when incubated with living parasite, is reduced by live mitochondria to yield dark blue formazan within the cells, the formazan formed is extracted with DMSO and quantitated colorimetrically, during the assay. The very low absorbance value $(<0.323)$ observed for the heat-killed worms was due to the less production of formazan in dead worms. The percentage inhibition ( $>50 \%$ ) was considered significant, was achieved at concentrations $1.0,2.0$, and $5.0 \mathrm{mg} / \mathrm{mL}$ for Methanol, for Hexane-ethanol extract 5.0 and $10.0 \mathrm{mg} / \mathrm{mL}$, indicating the significant effect of the plant extract at lower concentrations considered as significant and for Ciprofloxacin it was 10.0 and $20.0 \mathrm{mg} / \mathrm{mL}$ (Table 2). Consequently, inhibitory concentration at which 50 per cent of the motility inhibition achieved (IC50), was calculated by plotting the graph of percentage reduction in MTT-assay against different concentrations of herbal drugs/Ciprofloxacin and the obtained values was for Methanol and Hexane-ethanol extract $1.25,3.6 \mathrm{mg} /$ $\mathrm{mL}$ respectively, while for Ciprofloxacin it was $7.5 \mathrm{mg} / \mathrm{mL}$. Both worm motility assay and MTT-reduction assay confirmed the significant macrofilaricidal activity of plant extracts but antibiotic Ciprofloxacin failed to show such similar activity against Setaria cervi.

\section{Disscusion}

In view of the huge socio-economic load of filarial disease, where this disease is much more prevalent, discovery and development of potent antifilarial curative drug candidate is essential. Herbal medicines are quite popular and are time tested for their safety, efficacy and cultural suitability. The plant based drugs are compatible to the human being. WHO has already referred this medicinal system in his TDR mandate [12].

During the present investigation an effort was made by screening of plant Butea monosperma $\mathrm{L}$. leaves extracts for antifilarial activity against Setaria cervi. This plant is a traditionally used medicinal plant in many Ayurvedic drug preparations in India, revealed promising adulticidal activity. In in vitro experiment Methanol extracts shown significant activity than Hexane-ethanol. Another study was carried out for same plant against Brugia malayi human filarial nematodeaqueous extracts of leaves and roots shown significant activity against Brugia malayi filarial nematode [13]. Butea also showed activity against intestinal worms [14]. Other study was also carried out by various workers with other plant extracts against Setaria cervi-Aqueous and alcoholic extracts of the leaves of Mallotus philippensis (Lam.) was reported antifilarial activity [16]. Alcoholic extract of Plumbago indiga [4], alcoholic and aqueous extracts extract of Azadirachta indica flowers [17] and Excoecaria agallocha L. leaves extracts [18] shown antifilarial activity. Effect of Asparagus adscendens Roxb [19], Effect of alcoholic and aqueous extracts of the fruits of the Ficus racemosa Linn., significantly inhibited the spontaneous movements of the whole worm. [20], ethyl acetate extract of Vitex negundo leaves [21], and in another study Methanolic

Table 2. Effect of Butea monosperma L. leaves extracts/Ciprofloxacin against adult filarial parasite Setaria cervi for 24 hrs incubation in terms of MTT reduction assay. Results shown are mean \pm SEM of percent reduction.

\begin{tabular}{|c|c|c|c|c|c|c|}
\hline Sample & Treatment & $\begin{array}{l}\text { Test concentration } \\
\left(\mathrm{mgmL}^{-1}\right)\end{array}$ & $\begin{array}{l}\text { Incubation } \\
\text { time(In hrs.) }\end{array}$ & $\begin{array}{l}\text { Absorbance at } 492 \mathrm{~nm} \\
\text { (mean } \pm \text { s.e.m.) }\end{array}$ & $\begin{array}{l}\% \text { reduction relative to solvent control }{ }^{\mathrm{C}} \text {, } \\
\text { heat killed }^{\mathrm{H}} \& \text { treated worms }^{\mathrm{T}}\end{array}$ & $\begin{array}{l}\text { IC50 } \\
\left(\mathrm{mgmL}^{-1}\right)\end{array}$ \\
\hline Methanol extract & $\begin{array}{l}{ }^{\mathrm{C}} \text { Control } \\
{ }^{\mathrm{H}} \text { Heat killed } \\
{ }^{\mathrm{T}} \text { Plant extract }\end{array}$ & $\begin{array}{l}-- \\
-- \\
0.25 \\
0.50 \\
1.00 \\
2.00 \\
5.00\end{array}$ & $\begin{array}{l}24 \\
0.5 \\
24.0 \\
20.0 \\
15.0 \\
10.0 \\
5.0\end{array}$ & $\begin{array}{l}1.006 \pm 0.003 \\
0.319 \pm 0.004 \\
0.912 \pm 0.009^{\star} \\
0.788 \pm 0.008^{\star} \\
0.622 \pm 0.006^{\star} \\
0.522 \pm 0.006^{\star} \\
0.336 \pm 0.005^{\star}\end{array}$ & $\begin{array}{l}-- \\
-- \\
14.2 \\
31.8 \\
56.3 \\
70.5 \\
97.6\end{array}$ & 1.25 \\
\hline $\begin{array}{l}\text { Hexane -ethanol } \\
\text { extract }\end{array}$ & $\begin{array}{l}{ }^{\mathrm{C}} \text { Control } \\
{ }^{\mathrm{H}} \text { Heat killed } \\
{ }^{\mathrm{T}} \text { Plant extract }\end{array}$ & $\begin{array}{l}-- \\
-- \\
0.50 \\
1.00 \\
2.00 \\
5.00 \\
10.0\end{array}$ & $\begin{array}{l}24 \\
0.5 \\
24.0 \\
20.0 \\
15.0 \\
10.0 \\
5.0\end{array}$ & $\begin{array}{l}1.008 \pm 0.002 \\
0.322 \pm 0.004 \\
0.955 \pm 0.005^{\star} \\
0.87 \pm 0.002^{\star} \\
0.745 \pm 0.002^{\star} \\
0.56 \pm 0.009^{\star} \\
0.345 \pm 0.003^{\star}\end{array}$ & $\begin{array}{l}-- \\
-- \\
7.8 \\
20.7 \\
38.4 \\
65.4 \\
96.7\end{array}$ & 3.6 \\
\hline Ciprofloxacin & $\begin{array}{l}{ }^{\mathrm{C}} \text { Control } \\
{ }^{\mathrm{H}} \text { Heat killed } \\
{ }^{\mathrm{T}} \text { Antibiotics }\end{array}$ & $\begin{array}{l}-- \\
-- \\
1.0 \\
2.0 \\
5.0 \\
10.0 \\
20.0\end{array}$ & $\begin{array}{l}24 \\
0.5 \\
24.0 \\
20.0 \\
15.0 \\
10.0 \\
5.0\end{array}$ & $\begin{array}{l}1.011 \pm 0.003 \\
0.323 \pm 0.001 \\
0.965 \pm 0.002^{\star} \\
0.886 \pm 0.004^{\star} \\
0.688 \pm 0.005^{\star} \\
0.551 \pm 0.011^{\star} \\
0.342 \pm 0.002^{\star}\end{array}$ & $\begin{array}{l}-- \\
-- \\
6.7 \\
18.2 \\
47 \\
66.9 \\
97.3\end{array}$ & 7.5 \\
\hline
\end{tabular}

\footnotetext{
${ }^{\mathrm{C}}$ Positive control, HNegative control, TTreated worm with extract/Ciprofloxacin

${ }^{*} \mathrm{P}$ value represents the level of significance $\mathrm{P}<0.05$ when comparing the mean value of absorbance observed for the formazan formed between treated and control worms.
} 
extract of leaves of Hibiscus mutabilis exhibited activity against Setaria cervi in vitro [22]. Ciprofloxacin was also assessed for antifilarial activity in present research. This antibiotic not showed much more activity as other two extracts used. In similar study Ciprofloxacin was shown antifilarial activity against Brugia malayi parasite [23]. Novobiocin antibiotics also found to be active in many experiment against Brugia malayi $[24,25]$.

These results revealed that some active molecules present in this plant extract might be responsible for the real antifilarial effect. Therefore, it would be interesting to find out the basis behind the pharmaceutical approach of this potential drug candidate in the light of phytochemical basis of this extract. Usage of herbal drugs in traditional medicine is well known and so now these herbals are largely being explored. In the present investigation methanolic extract found potent antifilarial drug revealed towards the importance of in depth study for design and development of new antifilarial therapeutic drug candidate; which may actually prove better in terms of cost effectiveness and patient fulfilment to combat this disease.

\section{Competing interest}

The authors declare that they have no competing interests.

\section{Authors' contributions}

\begin{tabular}{|l|c|c|c|c|c|}
\hline Authors' contributions & MD & KNS & RKP & BM & VS \\
\hline Research concept and design & -- & -- & -- & -- & $\checkmark$ \\
\hline Collection and/or assembly of data & $\checkmark$ & -- & $\checkmark$ & -- & -- \\
\hline Data analysis and interpretation & -- & $\checkmark$ & -- & -- & -- \\
\hline Writing the article & -- & $\checkmark$ & -- & $\checkmark$ & -- \\
\hline Critical revision of the article & -- & -- & -- & -- & $\checkmark$ \\
\hline Final approval of article & -- & -- & -- & -- & $\checkmark$ \\
\hline Statistical analysis & -- & $\checkmark$ & -- & -- & -- \\
\hline
\end{tabular}

\section{Acknowledgement}

This work was supported by the Research Associate project grant from Indian Council of Medical Research (ICMR), Govt. of India, New Delhi. Special thanks to Department of Microbiology of Brakatullah University, Bhopal, (M.P.) India, for providing all required facilities to conduct the experiments.

\section{Publication history}

Editors: Farzin Roohvand, Pasteur Institute of Iran, Iran.

Claudio Alejandro Pereira, University of Buenos Aires, Argentina. Received: 11-Nov-2013 Revised: 26-Dec-2013

Accepted: 11-Jan-2014 Published: 30-Jan-2014

\section{References}

1. World Health Organization. Eliminate filariasis: attack poverty: the global alliance for lymphatic filariasis. Proceedings of the First Meeting at Santiago de Compostela, Spain. Geneva, May 4-5 2002. I Pdf

2. Das PK, Ramaiah KD, Augustin DJ and Kumar A. Towards elimination of lymphatic filariasis in India. Trends Parasitol. 2001; 17:457-60. | Article I PubMed

3. Ramaiah KD, Kumar KN, Ramu K, Pani SP and Das PK. Functional impairment caused by lymphatic filariasis in rural areas of south India.
Trop Med Int Health. 1997; 2:832-8. | Article | PubMed

4. Mathew $\mathrm{N}$, Paily Abidha KP, Vanamail $P$, Kalyansundram $\mathrm{M}$ and Balraman K. Macrofilaricidal activity of plant Plumbago Indica/rosea In Vitro. Drug Dev Res. 2002; 56:33-39. | Article

5. Kamboj VP. Herbal medicine. Curr Sci. 2000; 78:35-9. | Pdf

6. Cragg GM and Newman DJ. Natural product drug discovery in the next millennium. Pharm Biol. 2001; 39 Suppl 1:8-17. | Article | PubMed

7. Kokate CK. Practical Pharmacognosy IV ed. Vallabh Prakashan, Delhi. 1993.

8. Malpani MO, Rajput PR, Mane VD and Deshpande AR. Phytochemical screening, characterization and in vitro antimicrobial activity of Butea monosperma flowers, leaves and gum: Methanolic and aqueous extract. International Journal of Chemistry Research. 2012; 3:17-20. I Pdf

9. Lakshmi V, Kumar R, Gupta P, Varshney V, Srivastava MN, Dikshit M, Murthy PK and Misra-Bhattacharya S. The antifilarial activity of a marine red alga, Botryocladia leptopoda, against experimental infections with animal and human filariae. Parasitol Res. 2004; 93:468-74. | Article | PubMed

10. Comley JC, Rees MJ, Turner CH and Jenkins DC. Colorimetric quantitation of filarial viability. Int J Parasitol. 1989; 19:77-83. | Article | PubMed

11. Strote G, Bonow I, Kromer M, Rubio de Kromer T, Attah S and Opoku N. Chemotherapy for onchocerciasis: results of in vitro experiments with promising new compounds. Trop Med Int Health. 1998; 3:397-407. | Article I PubMed

12. World Health Organization. The promotion and development of traditional medicine: report of a WHO meeting. World Health Organ Tech Rep Ser. 1978; 1-41. | PubMed

13. Sahare KN, Anandharaman V, Meshram VG, Meshram SU, Gajalakshmi $\mathrm{D}$, Goswami $\mathrm{K}$ and Reddy MV. In vitro effect of four herbal plants on the motility of Brugia malayi microfilariae. Indian J Med Res. 2008; 127:46771. | PubMed

14. Mukerji AK and Bhaduri NV. The treatment of intestinal worms with the indigenous drugs Butea, Embelia and kamala. Ind Med Gaz. 1947; 82:66-9. | PubMed

15. Sahare KN, Anandhrama V, Meshram VG, Meshram SU, Singh V, Reddy MVR and Goswami K. Antifilarial Potential of Butea monosperma L. against microfilaria in vitro. International Journal of PharmTech Research. 2012; 4:1181-1184. | Pdf

16. Singh R, Singhal KC and Khan NU. Antifilarial activity of Mallotus philippensis Lam. on Setaria cervie (Nematoda: Filarioidea) in vitro. Indian J Physiol Pharmacol. 1997; 41:397-403. | Pdf | PubMed

17. Mishra V, Parveen N, Singhal KC and Khan NU. Antifilarial activity of Azadirachta indica on cattle filarial parasite Setaria cervi. Fitoterapia. 2005; 76:54-61. | Article | PubMed

18. Patra JK, Mahapatra AD, Rath S, Dhal NK and Thatoi H. Screening of antioxidant and antifilarial activity of leaves extracts of Excoecaria agallocha L. International Journal of Integrative Biology. 2009; 7:9-15. | Pdf

19. Singh R, Khan NU and Singhal KC. Potential antifilarial activity of roots of Asparagus adscendens Roxb, against Setaria cervi in vitro. Indian J Exp Biol. 1997; 35:168-72. | PubMed

20. Mishra V, Khan NU and Singhal KC. Potential antifilarial activity of fruit extracts of Ficus racemosa Linn. against Setaria cervi in vitro. Indian J Exp Biol. 2005; 43:346-50. | Article | PubMed

21. Sahare KN and Singh V. Antifilarial activity of ethyl acetate extract of Vitex negundo leaves in vitro. Asian Pac J Trop Med. 2013; 6:689-92. I Article | PubMed

22. Saini P, Gayen P, Nayak A, Kumar D, Mukherjee N, Pal BC and Sinha Babu SP. Effect of ferulic acid from Hibiscus mutabilis on filarial parasite 
Deshmukh et al. Trends in Vector Research and Parasitology 2014,

http://www.hoajonline.com/journals/pdf/2054-9881-1-1.pdf

Setaria cervi: molecular and biochemical approaches. Parasitol Int. 2012; 61:520-31. | Article | PubMed

23. Mahajan RS, Veerpathran A, Dakshinamoorthy G, Sharma RD, Goswami $\mathrm{K}$ and Reddy MV. Effect of Certain Antibiotics Against Filarial Parasite Brugia malayi In Vitro: Possible Role of Oxidative Stress. Indian J Clin Biochem. 2010; 25:362-6. | Article | PubMed Abstract | PubMed Full $\underline{\text { Text }}$

24. Katiyar SB, Bansal I, Saxena JK and Chauhan PM. Syntheses of 2,4,6-trisubstituted pyrimidine derivatives as a new class of antifilarial topoisomerase II inhibitors. Bioorg Med Chem Lett. 2005; 15:47-50. | Article | PubMed

25. Kumar A, Saxena JK and Chauhan PM. Synthesis of 4-amino-5cyano-2, 6-disubstituted pyrimidines as a potential antifilarial DNA topoisomerase II inhibitors. Med Chem. 2008; 4:577-85. | Article | PubMed

\section{Citation:}

Deshmukh M, Sahare KN, Patidar RK, Mahajan B and Singh V. Antifilarial activity of Butea monosperma L. leaves extracts against Setaria cervi. Trends Vector Res Parasitol. 2014; 1:1.

http://dx.doi.org/10.7243/2054-9881-1-1 